Research Article

\title{
Antibiotic Resistance Results of Helicobacter pylori in a University Hospital: Comparison of the Hybridization Test and Real-Time Polymerase Chain Reaction
}

\author{
Zehra Kipritci $\mathbb{D}^{1},{ }^{1}$ Yesim Gurol $\mathbb{D D}^{2}{ }^{2}$ and Gulden Celik ${ }^{3}{ }^{3}$ \\ ${ }^{1}$ Yeditepe University Hospital, İstanbul, Turkey \\ ${ }^{2}$ Acıbadem University School of Medicine, Department of Clinical Microbiology, Istanbul, Turkey \\ ${ }^{3}$ Bahçeşehir University, Department of Clinical Microbiology, Istanbul, Turkey \\ Correspondence should be addressed to Yesim Gurol; yesim.gurol@acibadem.edu.tr
}

Received 1 July 2020; Revised 22 September 2020; Accepted 23 October 2020; Published 4 November 2020

Academic Editor: Faham Khamesipour

Copyright (C) 2020 Zehra Kipritci et al. This is an open access article distributed under the Creative Commons Attribution License, which permits unrestricted use, distribution, and reproduction in any medium, provided the original work is properly cited.

Aim. H. pylori is a bacterial pathogen in the human stomach which infects about $50 \%$ of the world population. Untreated infection can lead to various diseases leading to cancer. Some of the $H$. pylori strains are asymptomatic, but some of them cause more severe diseases. Standard treatment protocol used for the treatment of $H$. pylori infection is triple therapy, which includes omeprazole as a proton pump inhibitor (PPI) and two antibiotics usually consist of amoxicillin and clarithromycin or metronidazole. In the recent years, because of the increase in the rate of antibiotic resistance, the eradication rate has decreased. Materials and Methods. We evaluated 140 patients who applied to a university hospital gastroenterology department and underwent biopsy during endoscopy. In these patients, we analysed floroquinolone and clarithromycin resistance using the GenoType ${ }^{\circledR}$ HelicoDR (Hain Life Science, Germany). We also used the real-time method for clarithromycin resistance. Results. We found the number and rate of floroquinolone resistance as $20(25.6 \%)$ and clarithromycine resistance as 31 (39.7\%). With the real-time PCR method, we detected clarithromycine resistance in $26(33.3 \%)$ patients. These results were not statistically significant. Discussion and Conclusion. Our results show similarity to the other studies held in our country. There should be more studies for the policy of eradication through our country.

\section{Introduction}

H. pylori is a bacterial pathogen in the human stomach, which infects about $50 \%$ of the world population. It is usually transmitted in childhood, and in the absence of antibiotic treatment, life-long colonization occurs $[1,2]$. Infection by H. pylori causes gastritis initially and, if allowed to persist, can induce a range of pathologies such as peptic ulcers, atrophic gastritis, intestinal metaplasia, and gastric cancer. $H$. pylori colonization of the human stomach usually occurs in childhood, but most of $\mathrm{H}$. pylori-induced diseases occur in adulthood and persist in the oldest people, whereas none of these diseases develop in the majority of people infected with H. pylori $(>80 \%)$ and they are asymptomatic throughout their life. The inflammatory response to infection varies due to genetic predisposition to disease and environmental factors $[2,3]$.

The basis of $H$. pylori treatment is antibiotics. The eradication rates are low in children and the reinfection is frequent. The successful eradication treatment regimen has not yet been established despite the use of various treatment protocols. Colonization under the mucus layer reduces the direct effect of antibiotic. Stomach acid reduces the antibiotic effect, and bacteria easily form resistance to antibiotics; this may be the reason of treatment failures $[4,5]$.

For eradication and triple treatment of a proton pump inhibitor (PPI) or ranitidine bismuth and two antibiotics, most frequently, amoxicillin and clarithromycin are usually used [6]. The duration of triple treatment is still controversial and varies between 7 and 14 days, depending on the 
centers [4]. The most common used antibiotics are macrolides (clarithromycin or azithromycin), imidazole (metronidazole or tinidazol), amoxicillin, and tetracycline [6]. The most prescribed antibiotic against $H$. pylori used as a part of the triple therapy is clarithromycin. According to consensus conferences, when the resistance rate reaches $20 \%$, this antibiotic should not be used. Phase 3 trials in Europe have shown that when the prevalence of clarithromycin resistant is increased in $H$. pylori strains, the two antibiotics, PPI and bismuth, which are the four treatment modalities, should be the first line treatment method. Metronidazole can be used instead of clarithromycin because of resistance [6]. In the failure of $H$. pylori eradication, levofloxacin is used for the second drug, which is a fluoroquinolone group of antibiotics [7].

Although rapidly developing resistance problem is changing from country to country/region to region, $H$. pylori cannot be eradicated in $10-45 \%$ of triple therapy patients [4]. In developing countries, alternative antibiotic treatments are tested. These are four treatment, sequential treatment, and triple treatment which indicate other antibiotics such as levofloxacin, rifabutin, and furazolidane. Four treatment indicates bismuth, PPI, metronidazole, and tetracycline [6]. Antibiotic resistance of $H$. pylori is not regular in the world, low in developing countries, and low in developed countries consistent with prescribing frequency. For his reason, a sensitivity test is recommended before starting the treatment regimen [6]. Especially in developing countries such as Turkey, the detection of antibiotic resistance is important for the effectiveness of the treatment [7].

Due to the technical difficulties of culturing $H$. pylori and antibiograms, it is shown that easy and cheap methods are needed to determine resistance [8]. In the recent years, many molecular methods such as fluorescence in situ hybridization, PCR sequencing, real-time PCR, and in-line hybridization PCR have been developed as alternatives to conventional methods [9]. Clarithromycin resistance is determined by phenotypic and genotypic methods. Resistance detection with mutations such as A2142G, A2142C, A2143G, A2143G, and A2144G by molecular methods makes it easier and more accurate to obtain results [10]. These mutations are sought by PCR-RFLP using restriction endonucleases. Fluoroquinolone resistance is associated with mutations in 87 and 91 positions in the gyrA gene and has been shown to be detected by molecular methods [11].

Antibiotic resistance rates vary from region to region. Turkey also observed different rates of resistance in different regions. Our aim is to determine the resistance to clarithromycin and fluoroquinolones, which are the most commonly used antibiotics for $H$. pylori eradication, by the hybridization method which is a molecular method and to compare with the real-time PCR method.

\section{Materials and Methods}

The study was carried out approved with the ethical approval of the Yeditepe University Clinical Research Ethics Committee (decision no: 51/445). Gastric biopsy specimens taken during endoscopy from randomly selected 140 patients who were referred to the Gastroenterology Department of a University Hospital were placed in Nucliswab ${ }^{\circledR}$ (Salubris, USA) and delivered to the Clinical Microbiology laboratory. First DNAs obtained by DNA extraction were stored at $-20^{\circ} \mathrm{C}$. Gastric biopsy specimens first were crushed, and DNA isolation was carried out by using the QIAamp DNA Mini Kit (Qiagen, Hilden, Germany) extraction kit with the protocol recommended for the tissues.

2.1. Hybridization with the Genotype ${ }^{\circledR}$ HelicoDR (Hain Life Science, Germany) Kit. In the isolated DNAs, the presence of $H$. pylori and the presence of fluoroquinolone and clarithromycin resistance was investigated using the Genotype ${ }^{\circledR}$ HelicoDR (Hain Life Science, Germany) kit (Figure 1).

\subsection{Detection of Clarithromycin Resistance by Real-time PCR.} In order to demonstrate the clarithromycin resistance in DNA, a real-time PCR-based PCR hybridization test was performed to detect point mutations. A fragment of $267 \mathrm{bp}$ of the $23 \mathrm{~S}$ rRNA gene of $H$. Pylori was multiplied by using HPYS $\left(5^{\prime}-\right.$ TATGGTACCCGCATGATATTCCCATTAGCAGT- $\left.3^{\prime}\right)$ and HPYA ( $5^{\prime}$-TAAGAGCTCAGGTTAAGAGGATGCGTCAGT $\left.-\mathrm{C}-3^{\prime}\right)$ primers. The amplified product was detected with two probes: the sensor probe, $5^{\prime}$ labeled with LC-Red 640 and $3^{\prime}$ phosphorylated (5'-GGCAAGACGGAAAGACC-3'; nucleotides 2504 to 2520 ), which hybridized with the region containing the mutation sites, and the anchor probe, which hybridized three bases upstream from the former and was 3 labeled with fluorescein (5'-TGTAGTGGAGGTGAAAATTCCTCCTACCC-3'; nucleotides 2473 to 2501). Primers and probes were obtained from Sentromer DNA Technologies Ltd.

PCR and hybridization reactions were performed using a LightCycler thermocycler (Roche Diagnostics, Neuilly sur Seine, France). In the tubes of glass capillaries, $1,6 \mu \mathrm{lggCl}_{2}$ (25 mM), 0,4 $\mu \mathrm{l}$ forward and reverse primers (eachone $20 \mu \mathrm{M}$ ), $0,2 \mu \mathrm{l}$ anchor and sensor probes (eachone $20 \mu \mathrm{M}$ ), and $2 \mu \mathrm{l}$ FastStart DNA Master Hybridization probes (Roche diagnostics) and indicate $3 \mu \mathrm{l}$ DNA, and PCR mixture was prepared to have a total volume of $20 \mu \mathrm{l}$. The amplification program is as follows: In $95^{\circ} \mathrm{C} 10$ minute $(1$ cycle), (senaturation), in $95^{\circ} \mathrm{C} 0$ second, in $60^{\circ} \mathrm{C} 10$ second, in $72^{\circ} \mathrm{C} 17$ second ( 50 cycle), in $95^{\circ} \mathrm{C} 0$ second (1 cycle), (melting), in $5^{\circ} \mathrm{C} 30$ second ( 1 cycle) (cooling), and slow progress with a fluorescence drop of 0.1 o C in $85^{\circ} \mathrm{C}$. After the procedure was completed, the $T_{m}$ points were compared with the LightCycler instrument to evaluate.

Four different $T_{m}$ points are seen in the study. It is expected that, for the wild type strain, A2142C, A2142G, and A2143G mutant strains are detected as at approximately $61.5,58.0,53.0$, and $53.6[12]$.

\section{Results}

The study included 140 biopsy specimens taken from the Yeditepe University Gastroenterology Department. Patients' ages ranged from 19 to 73 years, and patients were randomly selected. 


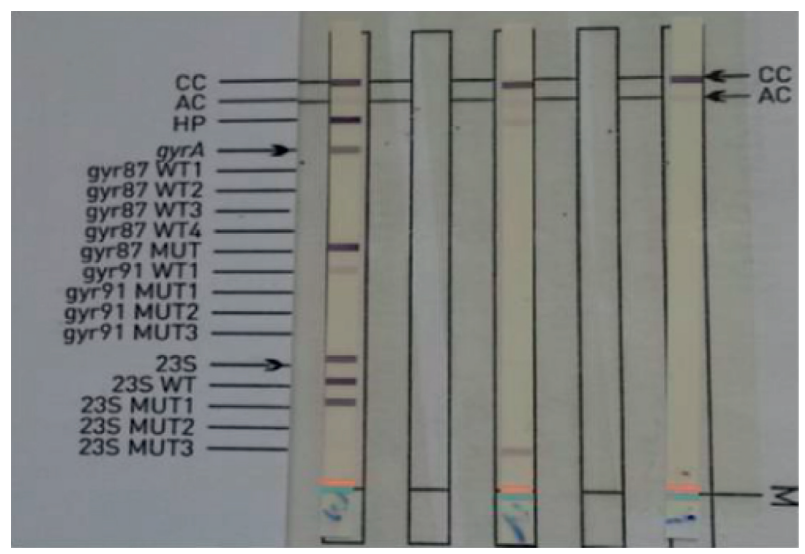

Figure 1: Patients who were $H$. pylori positive and negative with the Genotype ${ }^{\circledR}$ HelicoDR (Hain Life Science, Germany) kit. In the left patient HP band seen, the banding in the gyr87 MUT region is indicating a mutation in the gyrA region, that is, it is resistant to fluoroquinolone; at the same time, the region of $23 \mathrm{~S}$ with the WT in the MUT1 band is seen in the band, i.e., we can say that $H$. pylori strains isolated from this disease are resistant to clarithromycin. In the patient in the middle, the HP band can be seen but gyrA and $23 \mathrm{~S}$ bands cannot be seen. We can say that this patient is $H$. pylori positive. In the right patient, there is no band except for the control and amplification band, meaning that the patient has been evaluated as $H$. pylori negative.

Point mutations in the gyr87 and gyr91 gene regions were examined for the detection of resistance to fluoroquinolone antibiotics by using the Genotype ${ }^{\circledR}$ HelicoDR (Hain Life Science, Germany) kit. In this study, 78 patients were identified as positive. In these, 14 were found to be mutated in the gyr87 region, 6 in the gyr91 region, and 2 in both gene regions. A total of $20(25.6 \%)$ patients had mutation in the gyrA gene region, namely, fluoroquinolone resistance. Point mutations in the A2146G, A2146C, and $\mathrm{A} 2147 \mathrm{G}$ gene regions were examined for the detection of clarithromycin resistance using the Genotype ${ }^{\circledR}$ Helico DR (Hain Life Science, Germany) kit. Thirty-one (39.7\%) of 78 patients were found to have clarithromycin resistance. $38.7 \%$ of them has A2142G, $67.7 \%$ of them has A2143G mutation, and none has $\mathrm{A} 2142 \mathrm{C}$ mutation. Resistance to both fluoroquinolone and clarithromycin antibiotics was found in $11(14.1 \%)$ patients. The resistance of clarithromycin was determined by the real-time PCR method in point mutations of A2142G, A2142C, and A2143G gene regions in 78 patients who were detected $H$. pylori positive by the hybridization method. Twenty-six (33.3\%) patients were found to have clarithromycin resistance. $14.8 \%$ of them has A2142G, $85.2 \%$ of them has A2143G, and A2142C mutation is not detected. Comparing the results of hybridization and real-time PCR methods with clarithromycin resistance tests, mutation was detected in both methods in $24(30.8 \%)$ patients. Comparisons of these two tests were not statistically significant when $p$ value $>0.05$. It is accepted that the prekit is more accurate than the previous studies (Table 1).
Table 1: Antibiotic resistance rates of $H$. pylori-positive patients.

\begin{tabular}{lc}
\hline & $\begin{array}{c}\text { Genotype } \\
\text { DR }\end{array}$ \\
\hline $\begin{array}{l}\text { Fluoroquico } \\
\text { Clarithromycin resistance* }\end{array}$ & $20(25.6 \%)$ \\
$\begin{array}{l}\text { Fluoroquinolone and clarithromycin } \\
\text { resistance }\end{array}$ & $31(39.7 \%)$ \\
\hline
\end{tabular}

${ }^{*}$ Clarithromycin resistance was detected in $26(33.3 \%)$ patients also by the real-time PCR method.

\section{Discussion and Conclusions}

The standard treatment protocol for the eradication of $H$. pylori is triple therapy. It consists of a proton pump inhibitor (PPI) such as omeprazole and two antibiotics, usually amoxicillin, clarithromycin, or metranidazole. Studies have shown that this treatment eradicated approximately $80 \%$ of $H$. pylori at the beginning of the 1990 s. But, later, the eradication success rate dropped below $60 \%$. This is related to the increase of clarithromycin and metranidazole resistance in the world. Fluoroquinolones, such as levofloxacin and moxifloxacin, are often used as second-line treatment rescuers [11]. Antibiotic susceptibility testing should be performed according to the 5th Maastricht guideline published in 2017 if the second generation treatment fails [13].

Treatment failures are related to the age of the patient, cigarette use, bacterial burden before the treatment, genotype of the bacterium, and drug compliance of the patient. However, most of the treatment failures are due to resistance to the first choice antibiotics [7]. The use of similar antibiotics in different diseases causes to develop resistance to antibiotics. Sensitivity testing is recommended for antibiotics that can be used for increased resistance to antibiotics. Phenotypic methods for susceptibility testing are difficult because $H$. pylori is a slow-breeding bacterium under optimal culture conditions. Because the antibiotic resistance in this microorganism depends on the point mutation, it is more convenient to use genotypic methods as an alternative. Since these methods can be applied to direct biopsy material and stool specimens, it is an important step in getting faster results [6].

Clarithromycin is the most preferred antibiotic in $H$. pylori eradication, but the rate of eradication has decreased from $88 \%$ to $20 \%$ due to clarithromycin resistance. However, clarithromycin is still the first treatment option in the world $[7,11]$. Clarithromycin resistance is seen at different rates in different regions. The studies showed that clarithromycin resistance in Europe has increased from 9\% in 1998 to $17.6 \%$ in 2008. In Japan, the rate of resistance, which was $7 \%$ in 2000 , was $27.7 \%$ in 2006 [14]. According to studies conducted in France, the resistance of clarithromycin increased from $14.3 \%$ in 1997 to $22.2 \%$ in 2014 . According to the 5 Maastricht guidelines, when the resistance of clarithromycin is increased to over $20 \%$, second-line treatment should be applied by removing clarithromycin from the 
TABLe 2: Drug resistance of $H$. pylori in Turkey.

\begin{tabular}{|c|c|c|c|c|c|c|c|}
\hline Year/region & Method & KLA (\%) & $\operatorname{LEV}(\%)$ & MTZ (\%) & TE (\%) & $\operatorname{AMO}(\%)$ & References \\
\hline 2003/Ankara $(n=87)$ & PCR-RFLP & 27.6 & - & - & - & - & Bağlan et al. [24] \\
\hline $2007 /$ İzmir $(n=110)$ & RT PCR & 48.2 & - & - & - & - & Önder et al. [25] \\
\hline $2008 /$ Mersin $(n=37)$ & PCR-RFLP & 40.5 & - & - & - & - & Sezgin et al. [16] \\
\hline $\begin{array}{l}\text { 2011/Çukurova } \\
(n=79)\end{array}$ & $\begin{array}{l}\text { PCR- RFLP/Agar } \\
\text { dilusion }\end{array}$ & $7.7 / 8.9$ & - & - & - & - & Yula et al. [17] \\
\hline $\begin{array}{l}\text { 2013/Mersin }(n=94 / \\
11)\end{array}$ & PCR-RFLP/E-test & $\begin{array}{l}18.1 / \\
18.2\end{array}$ & - & $\begin{array}{l}45.5(\mathrm{E}- \\
\text { test) }\end{array}$ & $\begin{array}{l}9.1(\mathrm{E}- \\
\text { test })\end{array}$ & 0 & Çağdaş et al. [21] \\
\hline $2015 /$ İstanbul $(n=98)$ & E-test & 36.7 & 29.5 & 35.5 & 0 & 0 & Çalışkan et al. [7] \\
\hline 2015/Ankara $(n=93)$ & E-test & 30.1 & - & 48.4 & 0 & 0 & Maçin et al. [18] \\
\hline 2016/İstanbul $(n=78)$ & RT PCR/Helico DR & $\begin{array}{l}33.3 / \\
39.7\end{array}$ & 25.6 & - & - & - & Kipritçi et al. (this article) \\
\hline
\end{tabular}

CLA: clarithromycin, LEV: levofloxacin, MTZ: metronidazole, TE: tetracycline, AMO: amoxicillin, $n$ : total number of patients worked.

treatment [15]. The clarithromycin resistance in Turkey is between $16.4 \%$ and $48.2 \%$. The resistance of clarithromycin was found to be $40.5 \%$ in 2008 by Sezgin et al. in Mersin [16]. In the study conducted in the Çukurova region in 2011, the resistance of clarithromycin was found to be $7.7 \%$ by Yula et al. [17], 36.7\% in the year 2013 [7], and Maçin et al. found $30.1 \%$ in Ankara in 2015 [18].

In our study, clarithromycin resistance was found to be $39.7 \%$ with the Genotype ${ }^{\circledR}$ HelicoDR (Hain Life Science, Germany) kit and $33.3 \%$ with the real-time PCR method. These results demonstrate familiarity with the average resistance rate detected in Turkey with other studies.

The Genotype ${ }^{\circledR}$ HelicoDR (Hain Life Science, Germany) kit is used as a hybridization kit; Cambau et al. (2006-2009) conducted studies in France to compare the clarithromycin and fluoroquinolone resistance rates with MIC (E-test) methods. In this study, the sensitivity and specificity rates were 94 and $98 \%$ in the clarithromycin resistance test and 87 and $98.5 \%$ in the levofloxacin resistance test, respectively [11].

Levofloxacin is a fluoroquinolone whose activity against H. pylori is important. It is used as a secondary drug in failure of $H$. pylori eradication [19]. However, the number of studies on levofloxacin resistance is less [20]. According to one study, eradication rate is $80.8 \%$ with clarithromycin over $96 \%$ when levofloxacin was used [19]. In the study performed by Caliskan et al., the rate of resistance to levofloxacin was $29.5 \%$ [7]. Çağdaș et al. found the rate of levofloxacin resistance as 18.2\% [21]. In Brazil, Martins and colleagues found $11.1 \%$ [22]. In Pakistan, the rate of levofloxacin resistance was $62.3 \%$ in the study conducted by Rajper et al. [23]. In this study, which we conducted with the same method, the rate of fluoroquinolone resistance was found to be $25.6 \%$. This rate is generally correlated well with the rate of fluoroquinolone resistance in Turkey (Table 2).

The resistance rates are increasing worldwide. For this reason, susceptibility testing should be performed before treatment, but molecular methods are preferred to obtain faster and more accurate results than $H$. pylori infection. Molecular methods are also expensive and seem difficult to use on a routine basis. The European Helicobacter and microbiota working group (EHMSG) and also in Turkey, the $H$. pylori working group of Gastroenterological Association support make more and larger studies on these bacteria. The guides such as the Maastricht V/Florence Consensus Report by EHMSG contains recent information about $H$. pylori. For update, especially for the eradication, there should be more studies conducted in this field.

\section{Data Availability}

The data used to support the findings of this study are included within the article.

\section{Conflicts of Interest}

There are no conflicts of interest regarding this article.

\section{References}

[1] D. R. Bridge and D. S. Merrell, "Polymorphism in the Helicobacter pylori CagA and VacA toxins and disease," Gut Microbes, vol. 4, no. 2, pp. 101-117, 2013.

[2] K. Robinson, R. H. Argent, and J. C. Atherton, "The inflammatory and immune response to Helicobacter pylori infection," Best Practice \& Research Clinical Gastroenterology, vol. 21, no. 2, pp. 237-259, 2007.

[3] D. N. Baldwin, B. Shepherd, P. Kraemer et al., "Identification of Helicobacter pylori genes that contribute to stomach colonization," Infection and Immunity, vol. 75, no. 2, pp. 1005-1016, 2007.

[4] Y. Usta and H. Özen, "Helicobacter pylori Enfeksiyonu," Çocuk Sağlığı Ve Hastalıkları Dergisi, vol. 50, pp. 136-145, 2007.

[5] H. Uzunismail, "Helicobacter pylori ve Eradikasyon," in Gastrointestinal Sistem Hastalikları Sempozyumu, pp. 19-26, Hyperkitap, in Istanbul, Turkey, 2001.

[6] F. F. Vale, M. R. Rosa, and M. Oleastro, "Helicobacter pylori resistance to antibiotics," Science Against Microbial Pathogens: Communicating Current Research and Technological Advances, Badajoz: Formatex Research Center, Badajoz, Spain, 2011.

[7] R. Caliskan, H. B. Tokman, Y. Erzin et al., "Antimicrobial resistance of Helicobacter pylori strains to five antibiotics, including levofloxacin, in Northwestern Turkey," Revista da Sociedade Brasileira de Medicina Tropical, vol. 48, no. 3, pp. 278-284, 2015.

[8] E. Demiray and Ö. Yılmaz, "Helicobacter pylori'de antibiyotik direnci ve direncin saptanmasında kullanılan moleküler yöntemler," Mikrobiyoloji Bülteni, vol. 39, pp. 399-408, 2005. 
[9] C. Alba, A. Blanco, and T. Alarcón, "Antibiotic resistance in Helicobacter pylori," Current Opinion in Infectious Diseases, vol. 30, no. 5, pp. 489-497, 2017.

[10] P. H. Bağlan, G. Bozdayı, M. Özkan, and A. Özden, "Klaritromisin dirençli Helicobacter pylori'nin saptanmasında, E-test ve agar dilüsyon metodlarının karşılaştırılması," Akademik Gastroenteroloji Dergisi, vol. 4, no. 2, pp. 83-87, 2005.

[11] E. Cambau, V. Allerheiligen, C. Coulon et al., "Evaluation of a new test, genotype helicoDR, for molecular detection of antibiotic resistance in Helicobacter pylori," Journal of Clinical Microbiology, vol. 47, no. 11, pp. 3600-3607, 2009.

[12] M. Oleastro, A. Menard, A. Santos et al., "Real-time PCR assay for rapid and accurate detection of point mutations conferring resistance to clarithromycin in Helicobacter pylori," Journal of Clinical Microbiology, vol. 41, no. 1, pp. 397-402, 2003.

[13] P. Malfertheiner, F. Megraud, C. A. O'Morain et al., "European Helicobacter and microbiota study group (EHSG) and consensus panel. management of Helicobacter pylori infection-the Maastricht V/florence consensus report," Gut, vol. 66, no. 1, pp. 6-30, 2017.

[14] T. Nishizawa and H. Suzuki, "Mechanisms of Helicobacter pylori antibiotic resistance and molecular testing," Frontiers in Molecular Biosciences, vol. 119 pages, 2014.

[15] A. Ducornau, L. Benejat, E. Sifre, E. Bessède, P. Lehours, and F. Mégraud, "Helicobacter pylori resistance to antibiotics in 2014 in France detected by phenotypic and genotypic methods," Clinical Microbiology and Infection, vol. 22, no. 8, pp. 715-718, 2016.

[16] O. Sezgin, G. Aslan, E. Altıntaş, S. Tezcan, M. S. Serin, and G. Emekdaş, "Detection of point mutations on $23 \mathrm{~S}$ rRNA of Helicobacter pylori and resistance to clarithromycin with PCR-RFLP in gastric biopsy specimens in Mersin. Turkey," Turkish Journal of Gastroenterology, vol. 19, no. 3, pp. 163-167, 2008.

[17] E. Yula, T. Nagiyev, Ö. A. Kaya, M. İnci, M. M. Çelik, and F. Köksal, "Detection of primary clarithromycin resistance of Helicobacter pylori and association between cagA $(+)$ status and clinical outcome," Folia Microbiologica, vol. 58, no. 2, pp. 141-146, 2013.

[18] S. Maçin, H. Demir, H. Özen, A. Yuce, and Y. Akyön, "Determination of Helicobacter pylori antibiotic resistance patterns in pediatric gastroenterology patients: the hacettepe experience," The Turkish Journal of Pediatrics, vol. 57, no. 3, pp. 254-257, 2015.

[19] M. Safavi, R. Sabourian, and A. Foroumadi, "Treatment of Helicobacter pylori infection: current and future insights," World Journal of Clinical Cases, vol. 4, no. 1, pp. 5-19, 2016.

[20] I. Thung, H. Aramin, V. Vavinskaya et al., "Review article: the global emergence of Helicobacter pylori antibiotic resistance," Alimentary Pharmacology \& Therapeutics, vol. 43, no. 4, pp. 514-533, 2016.

[21] U. Çağdaş, F. Otağ, and S. Tezcan, "Ve ark. mide biyopsi örneklerinden Helicobacter pylori' nin tanımlanması ve antimikrobiyal direncinin araştırılması," Mikrobiyoloji Bülteni, vol. 46, no. 3, pp. 398-409, 2012.

[22] G. M. Martins, B. S. F. Sanches, L. D. Moretzsohn et al., "Molecular detection of clarithromycin and fluoroquinolones resistance in Helicobacter pylori infection, directly applied to gastric biopsies, in an urban Brazilian population," Arquivos de Gastroenterologia, vol. 53, no. 2, pp. 113-117, 2016.

[23] S. Rajper, E. Khan, Z. Ahmad, S. M. Alam, A. Akbar, and R. Hasan, "Macrolide and fluoroquinolone resistance in Helicobacter pylori isolates: an experience at a tertiary care centre in Pakistan," JPMA. The Journal of the Pakistan Medical Association, vol. 62, no. 11, pp. 1140-1144, 2012.

[24] P. H. Bağlan, G. Bozday1, M. Özkan, K. Ahmed, A. M. Bozdayi, and A. Ozden, "Clarithromycin resistance prevalence and iceA gene status in Helicobacter pylori clinical isolates in Turkish patients with duodenal ulcer and functional dyspepsia," Journal of Microbiology, vol. 44, no. 4, pp. 409-416, 2006.

[25] G. Önder, A. Aydin, U. Akarca, F. Tekin, O. Ozutemiz, and T. Ilter, "High Helicobacter pylori resistance rate to clarithromycin in Turkey," Journal of Clinical Gastroenterology, vol. 41, no. 8, pp. 747-750, 2007. 